\title{
Astrobiological Field Campaign to a Volcanosedimentary Mars Analogue Methane Producing Subsurface Protected Ecosystem: Imuruk Lake (Alaska)
}

\author{
F. Gómez, ${ }^{1}$ O. Prieto-Ballesteros, ${ }^{1}$ D. Fernández-Remolar, ${ }^{1}$ \\ J. A. Rodríguez-Manfredi, ${ }^{1}$ M. Fernández-Sampedro, ${ }^{1}$ M. Postigo Cacho, ${ }^{1}$ \\ J. Torres Redondo, ${ }^{1}$ N. Rodríguez, ${ }^{1}$ J. Gómez-Elvira, ${ }^{1}$ and R. Amils ${ }^{1,2}$ \\ ${ }^{1}$ Centro de Astrobiologia (CAB), INTA-CSIC, Carretera de Ajalvir Km 4, Torrejón de Ardoz, 28850 Madrid, Spain \\ ${ }^{2}$ Centro de Biología Molecular, Universidad Autónoma de Madrid/CSIC (UAM/CSIC), Cantoblanco, 28049 Madrid, Spain \\ Correspondence should be addressed to F. Gómez, gomezgf@cab.inta-csic.es
}

Received 29 September 2011; Revised 10 December 2011; Accepted 23 December 2011

Academic Editor: Wing Huen Ip

Copyright () 2011 F. Gómez et al. This is an open access article distributed under the Creative Commons Attribution License, which permits unrestricted use, distribution, and reproduction in any medium, provided the original work is properly cited.

Viking missions reported adverse conditions for life in Mars surface. High hydrogen signal obtained by Mars orbiters has increased the interest in subsurface prospection as putative protected Mars environment with life potential. Permafrost has attracted considerable interest from an astrobiological point of view due to the recently reported results from the Mars exploration rovers. Considerable studies have been developed on extreme ecosystems and permafrost in particular, to evaluate the possibility of life on Mars and to test specific automated life detection instruments for space missions. The biodiversity of permafrost located on the Bering Land Bridge National Preserve has been studied as an example of subsurface protected niche of astrobiological interest. Different conventional (enrichment and isolation) and molecular ecology techniques (cloning, fluorescence "in situ" probe hybridization, FISH) have been used for isolation and bacterial identification.

\section{Introduction}

Due to the reported Mars surface environmental conditions [1] (oxidative stress, high UV radiation levels, etc.) the possibility for life development in the surface of the red planet is very small. The identification of water ice on the subsurface on Mars by the Thermal Emission Spectrometer onboard of the Mars Odyssey [2] and from the High Energy Neutron Detector [3] has important astrobiological connotations [4], because in addition to being a potential source for water, these locations are shielding habitats against the harsh conditions existing on the planet, like UV radiation $[5,6]$.

Several authors have discussed similarities between Earth and Martian permafrost [7] and the structures that could play a protective role for subsurface ecosystems [8].

Chemolithotrophic microorganisms have the ability to use inorganic compounds, like reduced minerals, as energy source for its metabolism in isolate environments of the subsurface. Those microorganisms and environments have attracted considerable interest from an astrobiological point of view. Field campaigns for a better understanding of permafrost ecosystems on Earth are needed to evaluate the possibilities that life could have to develop in these types of structures on Mars. Permafrost on Earth is located at circumpolar latitudes. Of special interest is the permafrost on volcanic areas due to their similarities with Mars geology [9].

With the idea of a future development of instrumentation for automated remote life detection systems on permafrost, three main objectives were considered during the expedition: (1) permafrost localization and characterization by geophysical techniques and drilling; (2) microbial diversity analysis, with special interest on deeper part of the column, the oldest part of the permafrost; define pattern preservation of biosignatures in cold environment which is of extraordinaire astrobiological interest for future missions to Mars; (3) understanding cold ecosystem functional model to facilitate permafrost niches detection and mapping to implement new instrumentation for detection and mapping of permafrost 


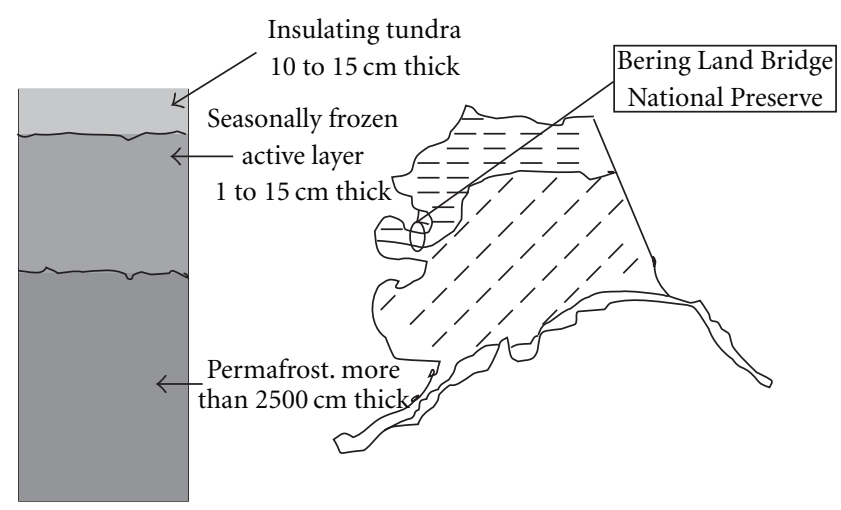

Permafrost in Alaska

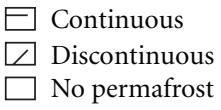

Figure 1: Bering Land Bridge National Preserve situation. Imuruk Lake is located on a volcanic area.

niches where life (or biochemical tracers of past life) may be preserved. Those new techniques will be of special interest for future automated astrobiological missions to Mars.

Future space missions will be focused on searching for life on the subsurface of Mars. New techniques and methodologies for studying these putative habitats need to be developed [7].

\section{Material and Methods}

2.1. Imuruk Lake Campaign. We identified an interesting volcanic area associated with permafrost in the region of Imuruk Lake (Alaska). An exploration campaign was developed during July 2005 to study the geology and microbiology of the area. Imuruk Lake is located at $65.6^{\circ} \mathrm{N}, 163^{\circ} \mathrm{W}$. This region is a volcanic area in the Bering Land Bridge National Preserve (Figure 1).

The 2005 campaign was developed in the eastern part of the lake, near Nimrod Hill. Previous geology studies [10] of the area have been reported. The area is characterized by volcanic formations with basaltic compositions. Some basalt lava flows are present. Over the lava structures there are two covers with different composition: the first is a wind blow silt layer and the second is a peat cover at the top. Some intermediate terraces can be found around the hill with sedimentary material.

An Arctic area has been selected for permafrost characterization. The field camping was developed on the Bering Land Bridge National Preserve (Figure 1). Permafrost was localized using geophysical sounding techniques over several traverse lines on the Imuruk Lake area. A particular place for sampling was chosen and a borehole four meters deep was drilled for sampling along the soil column. Active layer at the surface and subsequence permafrost were sampled at several depths. Samples were used for biodiversity determination using complementary techniques.
2.2. Geophysical Studies. A Syscal KID Switch-24 equipment was used for electrical resistivity tomography measurements (ERT). Thirteen parallel lines from the Imuruk Lake coast up to the hill of Imuruk formation were accomplished. Each ERT line was 48 meters long, using 2 meters as the spacing between each pair of electrodes. The space between lines was around 15 meters, depending on the difficulty of the topography for settling the electrical lines. Resulting ERT data indicate that the permafrost of the studied area is at a mean depth of 0.50 meter from the surface, sometimes even shallower. The presence of peat materials at the top of the stratigraphic column acts as an insulator layer, maintaining the low temperature of below very effectively. ERT survey reveals the occurrence of two units, an upper one of lower resistivity constituted by peat and silt with unfrozen water, vertically heterogeneous due to the structure of the polygonal terrains, and a lower one of higher resistivity associated with the development of permafrost in silt materials. Variations in resistivity in this lower unit reveal that permafrost in the southern part has a higher content in liquid water and decreases in thickness towards the central part of the studied area where the base could be located at around $6 \mathrm{~m}$ depth. In contrast, permafrost in the northern zone contains a lesser volume of liquid water and/or reaches a greater thickness.

2.3. Stratigraphic Column. Temperature recording during core sampling indicated a permafrost depth of around $30 \mathrm{~cm}$, but tomographic data indicated that permafrost began at a mean depth of 0.50 meter from the surface. After tomographic date interpretation a place for drilling was chosen.

A portable drilling system was used for stratigraphic and sampling at different depths. Cardi E-400 fuel-powered system was adapted for core retrieve. The dimension of the pits was 0.5 long and $50 \mathrm{~mm}$ diameter. Pits could joint each other to obtain a maximum depth core of $4 \mathrm{~m}$. Microbiological studies were performed over tomographic line 11 core. Maximum depth on this drill was $3.6 \mathrm{~m}$.

2.4. Mineralogy. Mineralogical determination of the core samples was analyzed by petrographic microscope and XRD. Petrology and optical mineralogy determination was achieved by petrographic microscopy. Polarized light microscopy was used for detailed description of rocks and soil samples from the site. Ultrathin sections were prepared for mineralogical analysis. The delicate nature of soil demands careful thin section sample preparation to avoid structural damage and disintegration. Water was removed from the soil. The sample was ventilated until a constant weight was achieved and then dried on a hotplate at $40^{\circ} \mathrm{C}$ for 48 hours. The soil was encapsulated and impregnated with synthetic resin on the IU30 Vacuum Impregnation Unit (Alogitech co.). Once the resin was cured, the sample was trimmed on the GTS1 cut-off saw (Alogitech co.). A non-aqueous solution was used as a coolant to avoid damaging the soil. Samples were polished on both faces under load in a conditioning ring on a LP50 Auto Lapping Machine system (Alogitech co.). When polishing was complete, the rock chips were mounted, polished side down, on a prepared glass slide, thinned, 
TABLE 1: Growth obtained on different inoculated media after $72 \mathrm{~h}$ of incubation at $12^{\circ} \mathrm{C}$.

\begin{tabular}{lcccccc}
\hline & $\mathrm{Fe}^{2+}$ & Het. & $\mathrm{P}$ & $\mathrm{M}$ & $\mathrm{F}$ & $\mathrm{VFA}$ \\
\hline $\mathrm{T} 11-1(30 \mathrm{~cm})$ & - & +++ & +++ Gas & +++ & ++ & ++ Gas \\
$\mathrm{T} 11-2(1 \mathrm{~m})$ & \pm & Gas & Gas & ++ & + & + \\
$\mathrm{T} 11-3(1.5 \mathrm{~m})$ & \pm & ++ & + & ++ & ++ & ++ \\
$\mathrm{T} 11-4(2.1 \mathrm{~m})$ & \pm & +++ & ++ & + & + & + \\
$\mathrm{T} 11-5(3.1 \mathrm{~m})$ & \pm & ++ & ++ & + & + & + \\
$\mathrm{T} 11-6(3.6 \mathrm{~m})$ & + & +++ & +++ & ++ & ++ & ++ \\
\hline
\end{tabular}

and lapped to $25-30 \mu \mathrm{m}$. Thereafter, the lapped section was polished using a PP5 Precision Polishing Jig on a soft metal plate to the required final thickness, down to less than $13 \mu \mathrm{m}$.

$\mathrm{X}$-Ray Diffraction: Sample mineral composition analysis was accomplished by X-ray diffraction. XRD was performed using a PANalytical X'Pert PRO MPD system (PW3040/60) (PANalytical B.V., The Netherlands) with $\mathrm{Cu} \mathrm{K} \alpha$ radiation $(\lambda=1.542 \AA)$ and a divergence slit of $1^{\circ}$. The X-ray generator was set to an acceleration voltage of $30 \mathrm{kV}$ and a filament emission of $40 \mathrm{~mA}$. Samples were scanned between $3^{\circ}(2 \theta)$ and $40^{\circ}(2 \theta)$ using a step size of $0.008^{\circ}(2 \theta)$ and a count time of $2 \mathrm{~s}$. Data were collected using X'Pert Data Collector and viewed using X'Pert Data Viewer (PANalytical B.V., The Netherlands). The intact compact samples were placed directly on a flat aluminum sample holder. The powdered compact samples were packed into a standard aluminum sample holder and measured in the same way as the calibration samples.

2.5. Elemental Chemical Analysis. Elemental composition of samples (carbon, sulphur, hydrogen, and nitrogen simultaneous percentage composition) was determined by microanalysis. This technique consists in the total oxidation of the sample by a complete combustion that transforms the sample to the combustion products as $\mathrm{CO}_{2}, \mathrm{H}_{2} \mathrm{O}, \mathrm{N}_{2}$, and $\mathrm{SO}_{2}$. An Elemental Analyzer LECO CHNS-932 was used for final gas products and chemical sample composition determination.

Cations composition in the samples was determined by ICP-M. The samples $(100 \mathrm{mg})$ were weighed accurately into a PFA vessel, and $2 \mathrm{~mL}$ of HF (46\%) was added. The vessel was capped and the mixture was allowed to react at room temperature for 5-6 hrs. The instrument used for this work was an inductively coupled plasma mass spectrometer, VG PlasmaQuad 3 (VG Elemental, Winsford, Cheshire, UK).

2.6. Microbial Diversity Studies. From ERT studies a particular place was chosen for drilling and sampling at several depths. The proximity of permafrost to the surface was the criteria chosen for drilling. Several core depths were chosen for microbiological analysis (Table 1). Some ice pockets were detected in line 11 (Figure 2). From every core depth selected for sampling two aliquots were used: the first one for direct media inoculation and the second for hybridization analysis. In the second case, the first step was to fix the sample with formaldehyde as soon as possible in order to maintain the structure of the microbial population without any alteration.

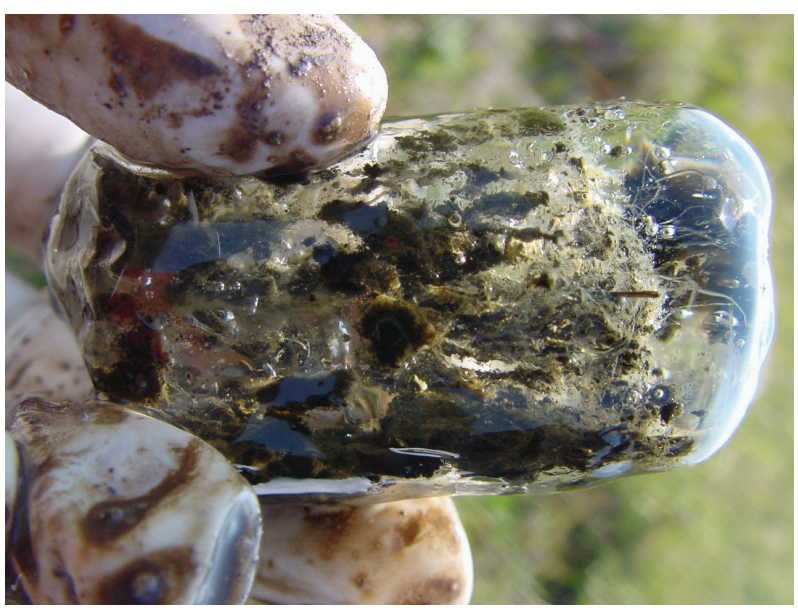

FIgUre 2: $0.8 \mathrm{~m}$ deep sample from tomographic line 11.

These fixed samples were transported to the laboratory for further processing and hybridization with DNA probes of different specificity (species, genus, and phylum).

Three different methodologies for microbial population analysis were used: (1) media inoculation for microbial enrichment. Three different media were chosen for microbial growth: chemolithotrophic media $\left(\mathrm{NaNO}_{3}: 1.5 \mathrm{~g}\right.$; $\mathrm{K}_{2} \mathrm{HPO}_{4}$ : $37.5 \mathrm{mg} ; \mathrm{MgSO}_{4} \cdot 7 \mathrm{H}_{2} \mathrm{O}: 37.5 \mathrm{mg} ; \mathrm{Na}_{2} \mathrm{CO}_{3}: 20 \mathrm{mg}$; $\mathrm{CaCl}_{2} \cdot 2 \mathrm{H}_{2} \mathrm{O}: 25 \mathrm{mg} ; \mathrm{Na}_{2} \mathrm{SiO}_{3} \cdot 9 \mathrm{H}_{2} \mathrm{O}: 58 \mathrm{mg}$; citric acid: $6 \mathrm{mg}$; distilled water $999 \mathrm{~mL}$ and $1 \mathrm{~mL}$ of metal solution, $\mathrm{pH}$ adjusted to 2.3 (metal solution composition: 1:1 distilled water plus $\mathrm{Na}_{2}$ EDTA: $0.750 \mathrm{~g} ; \mathrm{FeCl}_{3} \cdot 6 \mathrm{H}_{2} \mathrm{O}$ : $97 \mathrm{mg} ; \mathrm{MnCl}_{2} \cdot 4 \mathrm{H}_{2} \mathrm{O}: 41 \mathrm{mg} ; \mathrm{ZnCl}_{2}: 5 \mathrm{mg} ; \mathrm{CoCl}_{2} \cdot 6 \mathrm{H}_{2} \mathrm{O}$ : $2 \mathrm{mg} ; \mathrm{Na}_{2} \mathrm{MoO}_{4} \cdot 2 \mathrm{H}_{2} \mathrm{O}: 4 \mathrm{mg}$ ) enriched with ferrous iron, heterotrophic organic media (casein peptone tryptic digest: $10 \mathrm{~g}$; yeast extract: $5 \mathrm{~g}$; glucose: $5 \mathrm{~g} ; \mathrm{NaCl}: 5 \mathrm{~g}$; distilled water: $1000 \mathrm{~mL}, \mathrm{pH}$ adjusted to 7.2-7.4) and a basal anaerobic specific media $\left(\left(\mathrm{NH}_{4}\right)_{2} \mathrm{SO}_{4}, 132 \mathrm{mg} ; \mathrm{K}_{2} \mathrm{PO}_{4}: 41 \mathrm{mg}\right.$; $\mathrm{MgSO}_{4} \cdot 7 \mathrm{H}_{2} \mathrm{O}: 490 \mathrm{mg} ; \mathrm{CaCl} \cdot 2 \mathrm{H}_{2} \mathrm{O}: 9 \mathrm{mg} ; \mathrm{KCl}: 52 \mathrm{mg}$; $\mathrm{ZnSO}_{4} \cdot 7 \mathrm{H}_{2} \mathrm{O}: 1 \mathrm{mg} ; \mathrm{CuSO}_{4} \cdot 5 \mathrm{H}_{2} \mathrm{O}: 2 \mathrm{mg} ; \mathrm{MnSO}_{4} \cdot \mathrm{H}_{2} \mathrm{O}$ : $1 \mathrm{mg} ; \quad \mathrm{NaMoO}_{4} \cdot 2 \mathrm{H}_{2} \mathrm{O}: \quad 0.5 \mathrm{mg} ; \quad \mathrm{CoCl}_{2} \cdot 6 \mathrm{H}_{2} \mathrm{O}: 0.5 \mathrm{mg}$; $\mathrm{Na}_{2} \mathrm{SeO}_{4} \cdot 10 \mathrm{H}_{2} \mathrm{O}: 1 \mathrm{mg}$; NiCl$\cdot 6 \mathrm{H}_{2} \mathrm{O}: 1 \mathrm{mg}$; distilled water: $1000 \mathrm{~mL}, \mathrm{pH}$ adjusted to 1.9) enriched with different energy sources (methanol, formate, proteolytic, and volatile fatty acid). Growth was followed by optical density at $580 \mathrm{~nm}$ in a WPA Lightwave spectrophotometer. Qualitative values for growth were assigned depending on the slope of the growth curve. After growth, microbial populations were identified by $16 \mathrm{~S}$ rRNA amplification of DNA, cloning, and sequencing. (2) Fluorescence "in situ" hybridization techniques (FISH) with specific DNA probes were used for microorganism identification. The DNA probes used in this study were specific for bacteria and archaea domains, alfa-, beta-, and gammaproteobacteria subclasses, a CF (Cytophaga-Flavobacterium cluster) and a HGC (High G+C content bacterial cluster) specific group probes. Samples were directly fixed on the field with formaldehyde $(4 \% \mathrm{v} / \mathrm{v})$ and incubated at $4{ }^{\circ} \mathrm{C}$ for $2 \mathrm{~h}$. After incubation, samples were washed twice with PBS and filtered. Filters were stored under frozen conditions in PBS-ethanol (1:1). Samples from several depths were 
chosen for farther analysis with different DNA specific probes. Cell density was determined by cell counting with a microscope. Filters were dried and maintained at low temperature until further processing in the lab. (3) $16 \mathrm{~S}$ rDNA amplification, cloning, and sequencing. A commercial kit for DNA extraction that works quite well for natural soil samples, FastDNA Spin Kit for Soil BIO 101 (Q-BIOgene), was used in this study. For PCR, universal primers to sequence the complete $16 \mathrm{~S}$ rRNA genes (around $1492 \mathrm{bp}$ ) were used [11]. The mixture for the PCR reaction was 10x PCR buffer $(5 \mu \mathrm{L})$, dNTP mix $(2.5 \mathrm{mM})(5 \mu \mathrm{L})$, BSA $\left(3 \mathrm{mg} \mathrm{mL}^{-1}\right)$ $(5 \mu \mathrm{L}), 50$ pmol forward primer $(0.5 \mu \mathrm{L}), 50$ pmol reverse primer $(0.5 \mu \mathrm{L})$, target DNA $(1 \mu \mathrm{L}(100 \mathrm{ng}$ aprox. $))$, Taq DNA polymerase $\left(5 \mathrm{U}_{\mu} \mathrm{L}^{-1}\right)(0.5 \mu \mathrm{L})$, and Milli-Q water to a final volume of $50 \mu \mathrm{L}$.

The PCR reaction steps were 1 cycle of $5 \mathrm{~min}$ at $95^{\circ} \mathrm{C}, 35$ cycles of $\left(1 \mathrm{~min}\right.$ at $95^{\circ} \mathrm{C}, 1 \mathrm{~min}$. at $46^{\circ} \mathrm{C}$ (for Bacteria primers) or $52^{\circ} \mathrm{C}$ (for Archaea primers) and $3 \mathrm{~min}$ at $72^{\circ} \mathrm{C}$ ), 1 cycle of $\left(1 \mathrm{~min}\right.$ at $95^{\circ} \mathrm{C}, 1 \mathrm{~min}$ at $55^{\circ} \mathrm{C}, 10 \mathrm{~min}$ at $72^{\circ} \mathrm{C}$ ) finally $4^{\circ} \mathrm{C}$ constant.

16S rRNA gene cloning was achieved using the commercial kit pGEM-T and pGEM-T Easy Vector System (Promega) and TOPO-TA Cloning Kit (Invitrogen) for cloning genes of this size.

The extraction of the plasmid was carried out using the commercial kit Wizard Plus SV Minipreps DNA Purification System (Promega).

The PCR products were directly sequenced with dye terminator cycle sequencing kit (Big-Dye 1.1 sequencing kit, Applied Biosystems) as described in the manufacturer's instructions. The sequences were aligned to $16 \mathrm{~S}$ rRNA sequences obtained from the National Center of Biotechnology Information Database by the BLAST search. Automatic search for sequence similarities was done.

\section{Results and Discussion}

13 transects along the Nimrod hill were chosen for electrical resistivity tomography studies. 13 tomography lines were obtained. The existence of different resistivity values along the lines at different depths determined the presence of several units. Typical resistivity values of pits and sedimentary units were recorded. The tomography diagrams obtained from the 13 lines were used for permafrost localization (Figure 3), to determine the drilling points (vertical arrow in Figure 3) and the sampling depths for microbiology analysis. Samples were taken at $30 \mathrm{~cm}, 1 \mathrm{~m}, 1.5 \mathrm{~m}, 2.1 \mathrm{~m}, 3.1 \mathrm{~m}$, and $3.6 \mathrm{~m}$. From every sample two aliquots were taken.

3.1. T11 Stratigraphic Column. The T11 core, drilled from the ERT line 11, was 3.6 meters in depth. Below the peat, brown silt with organic matter was observed until 3.0 meters. The sand fraction of the silt consists of quartz, which originated from the surrounding granitoids, and plagioclases, while the fine fraction is made by clinochlore, montmorionite, illite, and vermiculite as was determined by XRD. From here to the core bottom the materials were greenyellowish silt, almost free of organic material. In this core,

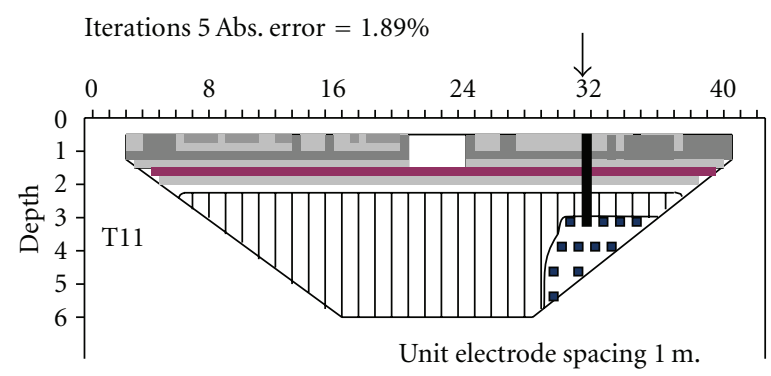

Inverse model resistivity sections

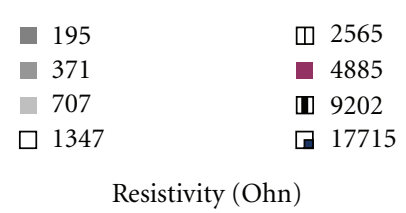

FIgURE 3: Electrical resistivity tomography for line 11. This section was chosen for drilling a $4 \mathrm{~m}$ deep borehole for microbial sampling.

the concentration of carbon has a maximum peak of $26 \%$ at $0.55 \mathrm{~m}$, but it decreases with depth (Figure 4). The peat should end at $0.6 \mathrm{~m}$. The silt from 0.6 to 2.5 has an average of $7 \% \mathrm{C}$, and, from 2.5 to $3.6 \mathrm{~m}$, the green silt has an average of $1.6 \% \mathrm{C}$. The trends of $\mathrm{H}, \mathrm{N}$, and $\mathrm{S}$ are well correlated with those of $\mathrm{C}$, except for $\mathrm{S}$ at $3 \mathrm{~m}$ where there is a positive anomaly (Figure 4 ).

Soluble cations ( $\mathrm{Na}, \mathrm{Mg}, \mathrm{Ca}$, and $\mathrm{K}$ ) are good indicators of the permafrost active layer fluctuation. These elements are mobilized when liquid water is present and they are concentrated above the ice table. T11 core lacks data from upper centimeters so this behavior is not registered. T11 data shows a positive anomaly at $1.1 \mathrm{~m}$ and $2.6 \mathrm{~m}$. The 1.1 anomaly is due mostly to $\mathrm{Na}$ and $\mathrm{K}$ that are correlated between them, and it is probablly related to the enrichment in feldspars of the sediment. In the $2.6 \mathrm{~m}$ anomaly, all the four cations contribute, and is related to the change in the mineralogy of the silt.

3.2. Microbial Diversity. Microbial growth was observed in most of the media. Table 1 shows the result obtained on the inoculated media after $72 \mathrm{~h}$ of incubation at $12^{\circ} \mathrm{C}(-$ : no growth; \pm : less growth; +++: very growth; Gas: indicates gas production during growth).

$\mathrm{Fe}^{2+}$ : basal media enriched with ferrous iron on aerobic conditions; Het.: enriched media for heterotrophic bacteria cultures under aerobic conditions; P: media enriched with peptone and yeast extract for proteolytic bacteria and cultured under anaerobic conditions; M: methanol enriched media under anaerobic conditions; F: formaldehyde enriched media under anaerobic conditions; VFA: volatile fatty acid (C2 plus C4) enriched media under anaerobic conditions.

Most efficient growth (Table 1) was obtained using heterotrophic media under aerobic and anaerobic conditions inoculated with samples from all along the column. There was no obvious relationship between depth and bacterial growth indicating that viable bacteria are present along the 


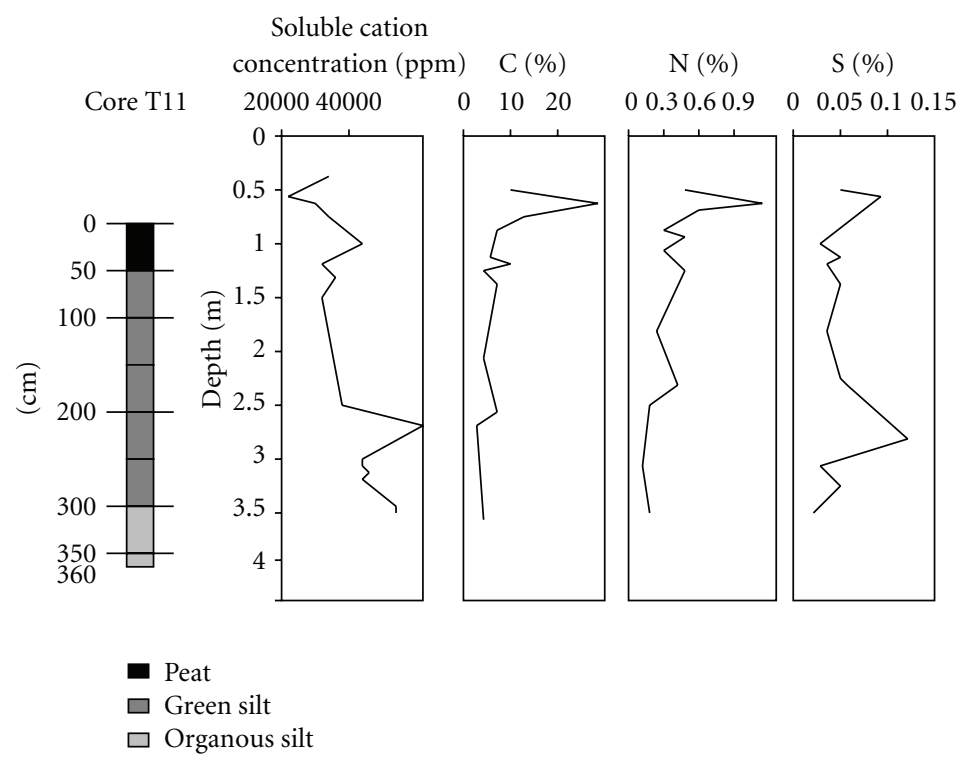

FIGURE 4: Lithology and distribution of soluble cation concentration, $\% \mathrm{C}, \% \mathrm{~N}$, and $\% \mathrm{~S}$ in core $\mathrm{T} 11$.

TABLE 2: Biodiversity from sample point T11-1 after microbial enrichment in several media and cloning and sequencing the 16S rDNA from total extracted DNA. T11-1 is the $30 \mathrm{~cm}$ deep sample from transect T11. Media: VFA minimal media enriched with volatile fatty acids. F: minimal media enriched with formaldehyde. P: minimal media enriched with peptone and yeast Extract, M: minimal media enriched with methanol, LB: organic media for heterotrophic aerobic bacteria. $\mathrm{Fe}^{2+}$ : minimal media enriched with ferrous iron. N.D.: no data.

\begin{tabular}{|c|c|c|c|c|}
\hline Culture & Blast result (NCBI database) & Gene bank ID number & Query coverage & Max. ident \\
\hline \multirow{4}{*}{ T11-1 VFA } & Unc. Proteobacterium & EF699933.1 & $100 \%$ & $99 \%$ \\
\hline & Shigella flexneri FBD002 & EU009187.1 & $100 \%$ & $99 \%$ \\
\hline & Unc. Archaeon SPS46 & AJ606292.1 & $10 \%$ & $100 \%$ \\
\hline & Unc. Propionibacterium 402C1 & AM420143.1 & $100 \%$ & $100 \%$ \\
\hline \multirow{2}{*}{ T11-1 F } & Psychrobacter sp. 9B & AY689064.1 & $100 \%$ & $98 \%$ \\
\hline & Antarctic sea water bac. BSW 10170 & DQ064630.1 & $100 \%$ & $98 \%$ \\
\hline T11-1 P & Unc. Archaeon SPS33 & AJ606279.1 & $19 \%$ & $100 \%$ \\
\hline T11-1 M & Citrobacter koseri СР000822.1 & СР000822.1 & $100 \%$ & $92 \%$ \\
\hline \multirow{2}{*}{ T11-1 LB } & Psychrobacter sp. 9B & AY689064.1 & $100 \%$ & $98 \%$ \\
\hline & Antarctic sea water bac. BSW 10170 & DQ064630.1 & $100 \%$ & $98 \%$ \\
\hline T11-1 $\mathrm{Fe}^{2+}$ & N.D. & & & \\
\hline
\end{tabular}

column, at all depths. Chemolithotrophic media produced less efficient growth indicating that chemolithotrophs were not present in high numbers on these ecosystems. The opposite was observed for heterotrophic microorganisms which have both aerobic and anaerobic representatives. Different microorganisms are present in the Imuruk Lake permafrost since different media gave positive growth. In the case of sample T11-1, growth was observed in heterotrophic media under aerobic conditions and in the basal media under anaerobic conditions enriched with peptone plus yeast extract, methanol, formaldehyde, and volatile fatty acids. There was also gas production in the media enriched with peptone and yeast extract, and VFA. These cultures inoculated with sample T11-1 were used for total DNA extraction, amplification, cloning, and sequencing of the 16S rRNA gene (Table 2). Gas production could be congruent with the presence of methanogenic bacteria [12]. Amplification, cloning, and sequencing of the $16 \mathrm{~S}$ rRNA confirmed this observation.

16S rDNA amplification from DNA extracted from cultures allowed to identify the presence of members of the Psychrobacter genus (Table 2). Also, the presence of some members of Propionibacterium genus was confirmed, which are characterized by anaerobic growth using fatty acids for energy uptakes with production of propionic acid.

Some uncultured Antarctic sea water representatives were also identified by $16 \mathrm{~S}$ rRNA sequencing.

Soil samples from several depths were hybridized with specie or genera specific DNA probes and compared with universal staining (DAPI) for cell counting and evaluation of cell density along the column. Figure 3 shows a universal stained microbial preparation of a sample from tomographic 


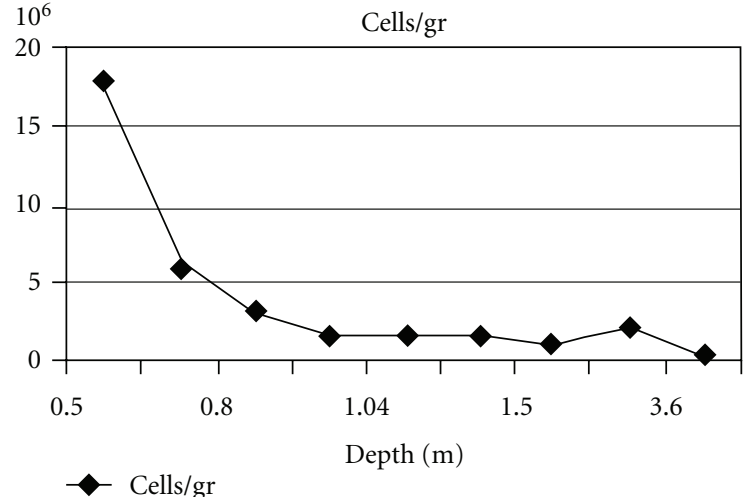

Figure 5: Population density (cells per gram of soil) gradient along the borehole from tomographic line 11 .

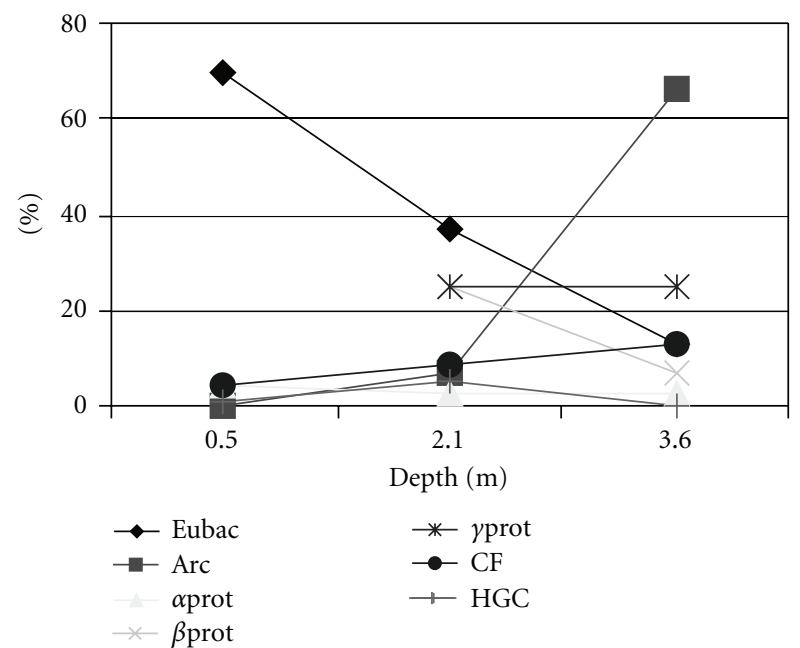

Figure 6: Percentage of different group pf microorganisms along the T11-1 column identified by FISH techniques.

line 11 obtained at a depth of $2 \mathrm{~m}$ bacterial counting by light microscopy was used for cell density quantification. Figure 5 shows the population gradient (cells/gr of soil) with depth.

The presence of active bacteria on frost soil was done by FISH techniques (Figure 6). Hybridization of the RNA probe is done over the $16 \mathrm{~S} \mathrm{rRNA}$, thus only active bacteria, some times uncultivable, can be detected. This technique requires the sample to be fixed at the moment of sampling to ensure the viability of the $16 \mathrm{~S}$ rRNA molecules population.

Population gradient along the core (Figure 5) was determined by direct counting of stained samples from $30 \mathrm{~cm}$, $1 \mathrm{~m}, 1.5 \mathrm{~m}, 2.1 \mathrm{~m}, 3.1 \mathrm{~m}$, and $3.6 \mathrm{~m}$ depth. Hybridized samples with genera and group specific DNA probes were counted to evaluate the correspondent percentage of the cell population (Figure 6).

Bacterial density decreased with depth (Figure 5) which is congruent with a permafrost model. An active layer develops during the summer on the first $50 \mathrm{~cm}$ cross-section of the crust and soil became completely frost down this depth all over the year. This active layer develops a dense active bacterial population that is reduced during winter due to lower temperatures. The permafrost model is congruent with lower bacterial density on all around the year frosted soil. An interesting result was the location of active bacteria under $50 \mathrm{~cm}$ depth. 16S rRNA sequencing results confirmed the presence Psychrobacter gen. representative's corroborating the results obtained in culture experiments and underlying the identification of active microorganisms on the frosted layer of the soil.

The cell density decreased with depth; The lower the depth lower the bacterial population, consequence of the harsh conditions of permafrost environments. But not only is the reduction on the bacterial number the interesting data reported by these experiments but the fact that several microorganism groups were detected all along the column (Figure 6). The percentage of every group varied with depth. On the first $50 \mathrm{~cm}$ of the soil column the main microbial population was composed by Bacteria. The presence of this type of microorganisms is constantly reduced with depth. While members of the domain Archaea have a low representation in the upper part of the column but its population increased with depth.

The Archaea identified on the grew media T11-1 P and T11-1 VFA (Table 2) are closely related with acetoclastic and hydrogenotrophic methanogens ([13] submitted to GenBank on 2003 with accession number AJ606292).

The viability of microorganisms on the permafrost was tested by sample inoculation on growth media and following the growth of the cultures. Figure 7 shows bacteria preparation from the aerobic heterotrophic media inoculated with a $3.6 \mathrm{~m}$ deep sample from T11 borehole. The quantification of every metabolic group of bacteria (Figure 8) was done by comparison of the total bacteria stained with the universal stain DAPI (Figure $7(\mathrm{a})$ ) and the positive hybridization signals with group specific DNA probes (Figure $7(b)$ ).

\section{Conclusions}

We are studying the permafrost in the Imuruk Lake volcanic field area (Alaska) from an astrobiological perspective. Permafrost studies like this will help to the planetary exploration and the planetary data interpretation because they work as an essential environmental reference to (1) define preservation patterns of biosignatures in cold environments that may be used in future space exploration missions, (2) develop new instrumentation for detecting life in situ and remotely, and (3) develop new instrumentation for detection and mapping of permafrost niches where life (or biochemical tracers of past life) may be preserved.

A complex metabolic network has been identified along the column in the permafrost of the studied area. Completely isolated from the surface an anaerobic ecosystem is active with interrelationships between its complementary parts. From aerobic psychrophiles to anaerobic methanogenic archaea, each element plays an important role in the integration of the complex network. An interesting gradient along the column related with temperature and oxygen concentration was identified. Abundant cells per mg of sample were detected in the first $60-70 \mathrm{~cm}$ of the column 


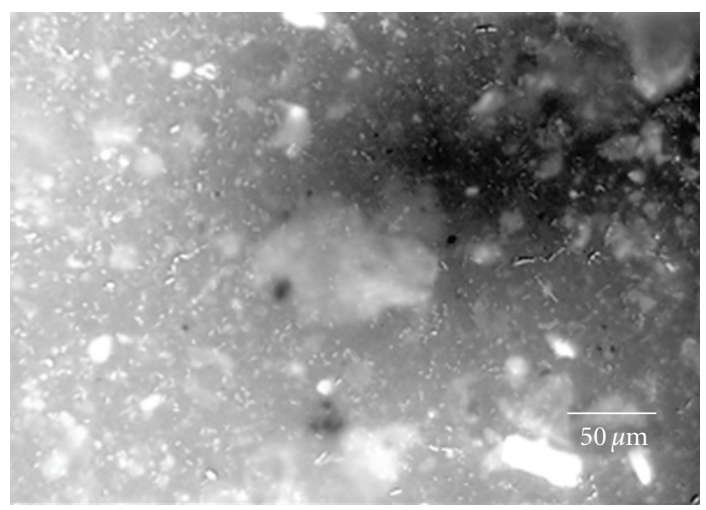

(a)

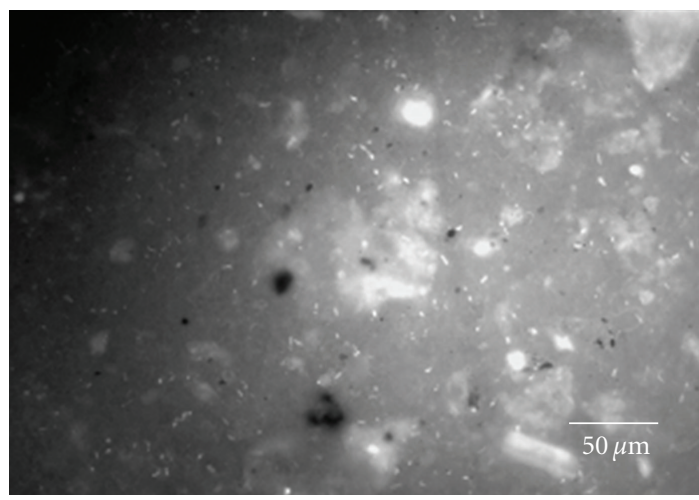

(b)

FIGURE 7: Universal staining DAPI preparation of a sample from the culture T-11-6 soil in heterotrophic media (a). Same culture preparation hybridized with Alphaproteobacteria specific DNA probe labeled with CY3 fluorophore (b). Bacteria are small white spots.

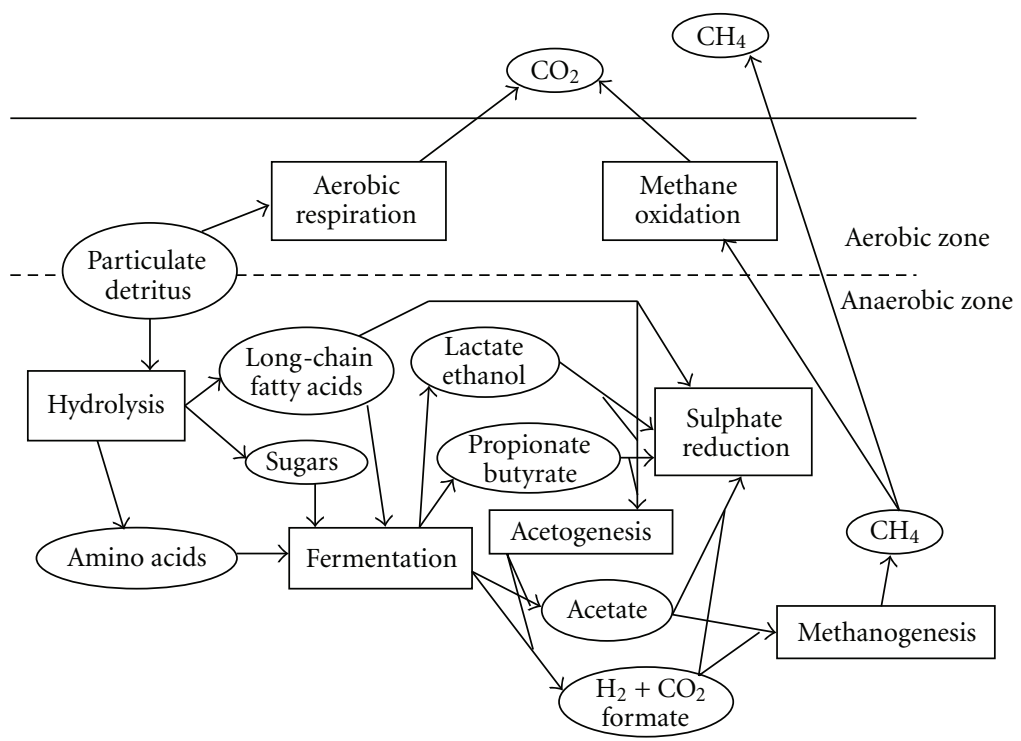

FIGURE 8: Metabolic activities detected in the samples from the area of study. Model of Imuruk's Lake area permafrost.

(the permafrost active layer). Accordingly to in situ hybridization and metabolic analysis an active microbial layer was detected on the first $60-70 \mathrm{~cm}$. Hybridization with specific $16 \mathrm{~S}$ rRNA probes reported the presence of high number of microorganisms from the Bacteria domain in the upper part of the column, which is congruent with the higher temperature reached at this depth during the summer. In contrast, deeper samples gave decreasing numbers for members of the bacterial domain while the cell density for Archaea started to grow. From $2.1 \mathrm{~m}$ depth to $3.6 \mathrm{~m}$ the Archaea are the most abundant. And it correlates with the fact that at this depth the soil is permanently frozen. The production of gas and the identification of archaeal related sequences on the T11-1 enrichment cultures are congruent with the presence of methanogenic Archaea and with the permafrost model (Figure 8).
These interdisciplinary field campaigns are needed in order to obtain a better understanding of extreme ecosystems whith important astrobiological implications. There are two main issues which are important for the interpretation of the future reported results from space astrobiological missions: the definition of limits of life but the comprehension of the functional model of the ecosystem as well. The development and testing of automated tools for application in future space missions is another important part of those campaigns.

The results reported in this paper are congruent with a putative ecosystem completely isolated from the surface and protected against possible harsh atmospheric conditions with the production of methane. The detection of this type of ecosystem in permafrost increases the possible existence of life in other planetary bodies like planet Mars, especially after 
the detection of methane in the Mars atmosphere by the Mars Express Planetary Fourier Spectrometer [14].

\section{Acknowledgments}

The expedition to Imuruk Lake was supported by Centro de Astrobiologia-INTA (Spain). The laboratory experimental procedures were supported by Grant AYA 201020213 "Desarrollo de Tecnología para la identificación de vida de forma automática" from the Spanish Government. The authors thank the Bering Land Preserve staff (US National Parks) for their help, especially to Dr. Chris Young and INTA and Dr. Juan Pérez-Mercader for helping during the campaign and later experimental work development.

\section{References}

[1] H. P. Klein, "The Viking biological experiments on Mars," Icarus, vol. 34, no. 3, pp. 666-674, 1978.

[2] H. H. Kieffer and T. N. Titus, "TES mapping of Mars' north seasonal cap," Icarus, vol. 154, no. 1, pp. 162-180, 2001.

[3] M. L. Litvak, I. G. Mitrofanov, A. S. Kozyrev et al., "Comparison between polar regions of Mars from HEND/Odyssey data," Icarus, vol. 180, no. 1, pp. 23-37, 2006.

[4] D. D. Wynn-Williams and H. G. M. Edwards, "Antarctic ecosystems as models for extraterrestrial surface habitats," Planetary and Space Science, vol. 48, no. 11, pp. 1065-1075, 2000.

[5] F. G. Gómez, A. G. Carles, L. Vázquez, and R. Amils, "UV radiation effects over microorganisms and study of protective agents," in Proceedings of the 3rd European Workshop on ExoAstrobiology, pp. 21-25, November 2003.

[6] F. Gómez, A. Aguilera, and R. Amils, "Soluble ferric iron as an effective protective agent against UV radiation: implications for early life," Icarus, vol. 191, no. 1, pp. 352-359, 2007.

[7] A. D. Frolov, "A review of the nature and geophysical studies of the thick permafrost in Siberia: relevance to exploration on Mars," Journal of Geophysical Research E, vol. 108, no. 4, pp. 8039-8046, 2003.

[8] D. A. Gilichinsky, G. S. Wilson, E. I. Friedmann et al., "Microbial populations in antarctic permafrost: biodiversity, state, age, and implication for astrobiology," Astrobiology, vol. 7, no. 2, pp. 275-311, 2007.

[9] M. D. Dyar and M. W. Schaefer, "Mossbauer spectroscopy on the surface of Mars-constraints and expectations," Earth and Planetary Science Letters, vol. 218, no. 3-4, pp. 243-259, 2004.

[10] D. M. Hopkins, "Geology of the Imuruk Lake area, Seward Peninsula, Alaska," U. S. Geological Survey Bulletin 1141-C, 1963.

[11] G. Muyzer, A. Teske, C. O. Wirsen, and H. W. Jannasch, "Phylogenetic relationships of Thiomicrospira species and their identification in deep-sea hydrothermal vent samples by denaturing gradient gel electrophoresis of 16S rDNA fragments," Archives of Microbiology, vol. 164, no. 3, pp. 165-172, 1995.

[12] O. R. Kotsyurbenko, "Trophic interactions in the methanogenic microbial community of low-temperature terrestrial ecosystems," FEMS Microbiology Ecology, vol. 53, no. 1, pp. 3-13, 2005.

[13] O. R. Kotsyurbenko, K. J. Chin, M. V. Glagolev et al., "Acetoclastic and hydrogenotrophic methane production and methanogenic populations in an acidic West-Siberian peat bog,"
Environmental Microbiology, vol. 6, no. 11, pp. 1159-1173, 2004.

[14] V. Formisano, S. Atreya, T. Encrenaz, N. Ignatiev, and M. Giuranna, "Detection of methane in the atmosphere of Mars," Science, vol. 306, no. 5702, pp. 1758-1761, 2004. 

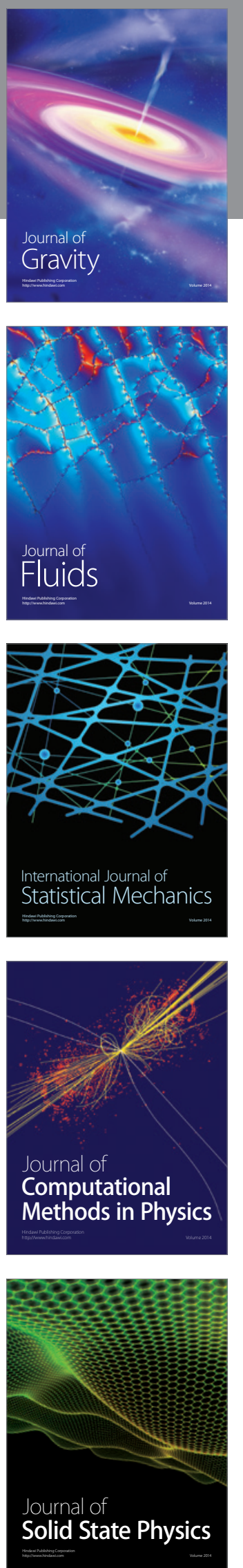

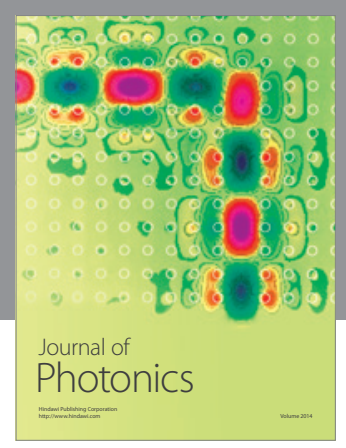

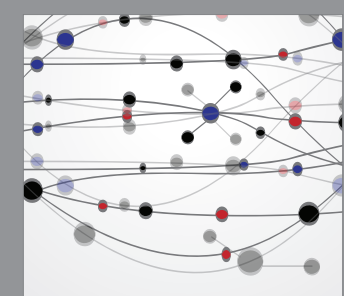

The Scientific World Journal
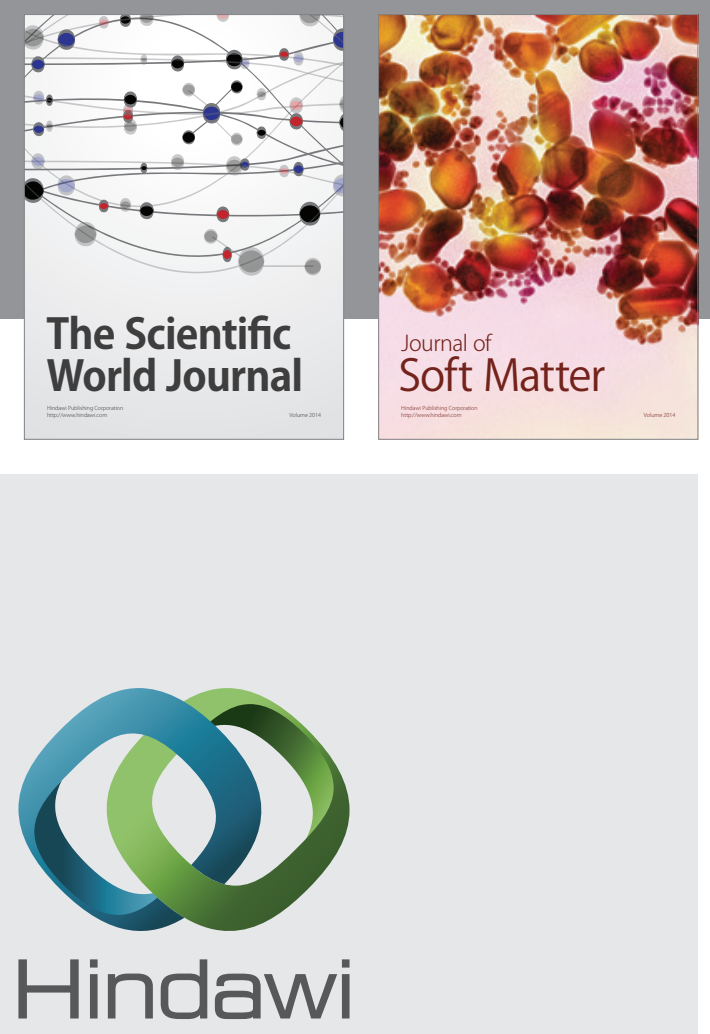

Submit your manuscripts at

http://www.hindawi.com
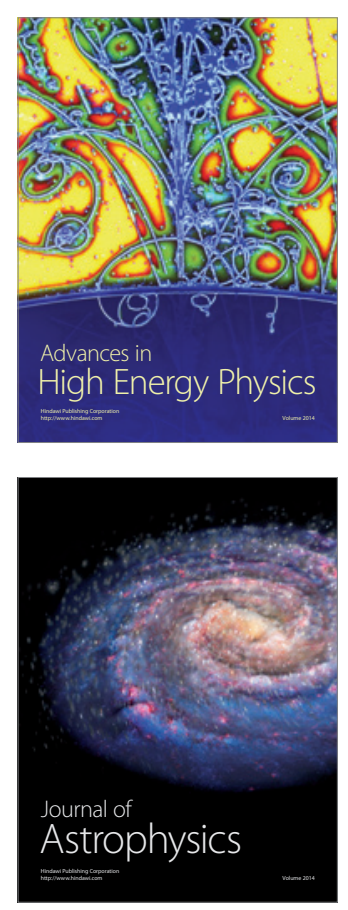
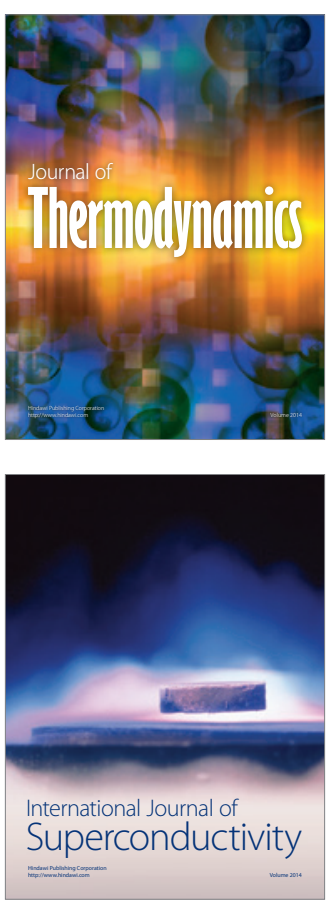
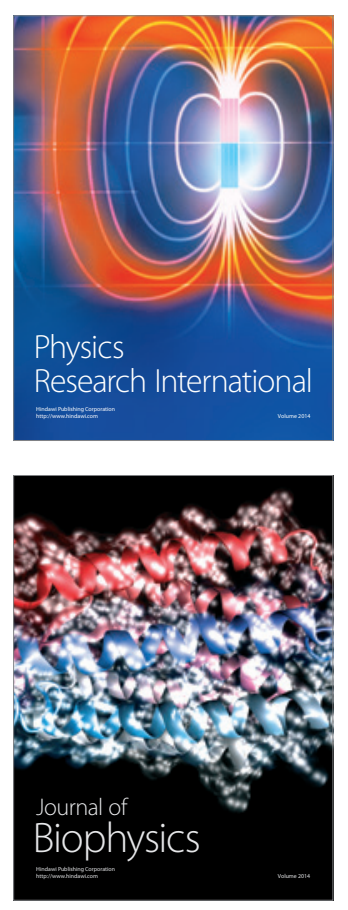
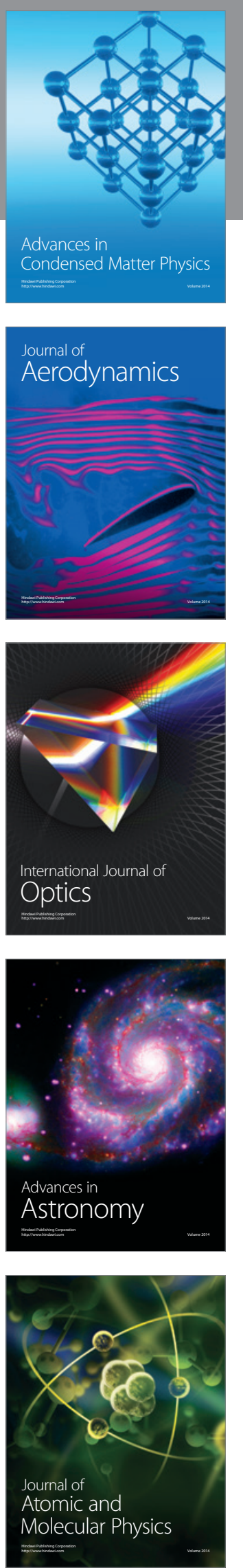